\title{
Determinants of Economic Development and Employability of Higher Education Institutions Graduates
}

\author{
Emilia Krajnakova ${ }^{1}$, Vaida Pilinkiene ${ }^{2}$, Patrik Bulko ${ }^{3}$
}

\author{
${ }^{1,3}$ Department of Management and Human Resources Development, Alexander Dubcek University \\ Trencin, 91150, Trencin, Slovakia \\ E-mail.emilia.krajnakova@tnuni.sk; patrik.bulko@tnuni.sk
}

${ }^{2}$ Kaunas University of Technology

K. Donelaicio st. 73, LT-44029, Kaunas, Lithuania

E-mail.vaida.pilinkiene@ktu.lt

cross $^{r e f}$ http://dx.doi.org/10.5755/j01.ee.31.2.24751

\begin{abstract}
The scope of the data presented in this study offers a comprehensive view of the issue of the higher education institutions graduates employability in the Czech Republic and Slovak Republic - related to determinants of economic development and their impact on them. The research studies of most authors are focused on the employability of graduates, especially in terms of competencies. However, the development of a competency model need not be the only assumption affecting graduates' employability. Therefore, we research the impact of economic determinants on their un/employment. This paper examines the impact of GDP, gross domestic expenditure on research and experimental development by only higher education sector and FDI on higher education institutions graduates' employability. The results indicate that correlation between unemployment of tertiary educated Slovaks and GDP, Gross domestic expenditure on research and development by higher education sector and FDI values was very strong. Correlation relationship of GDP and FDI in the conditions of Czech Republic was characterized as weak. On the other hand, correlation between employment of tertiary educated Czechs and the indicators of GDP, Gross domestic expenditure on research and experimental development by sector of higher education and FDI was significantly stronger (very strong to perfect in conditions of Slovak Republic, correlation between employment of tertiary educated Slovaks and GDP was almost perfect.
\end{abstract}

Keywords: Higher Education Institutions; Employment; Unemployment; Tertiary Education; Graduates; Economic Development.

\section{Introduction}

Although, there is extensive literature and research on the concept of employability and unemployability of tertiary educated persons, however, these studies are many times unilaterally focused only on competency models of graduates - many studies and papers investigate only the effect of competencies or higher education on likelihood to be successful on the labour market (Cao \& Bao, 2018; Krajnakova \& Vojtovic, 2017). Employability is a huge concept widely adopted by the researchers although its definition varies. The research on employability in this period was focused on the following important factors which affect employability, such as labour economics, public policies, social benefits system, applicants' performance during their interview, self-cognition (Su \& Zhang, 2015).

Many of global trends show the basic graduates' competency needs but they are not always the main key to success. In our study, we focus on the not yet sufficiently explored area - on the area of the impact of various determinants of economic development on the employment and unemployment of tertiary educated persons in the Czech Republic and in the Slovak Republic. It is more than obvious that the various economic (macroeconomic and microeconomic) determinants can have a significant impact on the employability and also unemployability of tertiary educated graduates. In connection with the above, we will try to explore the relationship between the selected determinants of economic development and the rate of employment and unemployment through selected analyses. The issue of graduates' employability is considered among the focuses of the state's government in different countries around the world (Aman \& Sitotaw, 2014). It is wellestablished fact, that tertiary educated graduates are often associated with low levels of unemployment. Graduates have been experiencing higher employment rates than graduates with lower education and that is why it is so necessary to work systematically to encourage young people to have a positive attitude towards education. The main aim of this research paper is to identify a causal link between un/employment of tertiary educated persons, both, in Slovak Republic and the Czech Republic, and the determinants of GDP, FDI and Gross domestic expenditure on research and development by higher education sector. Cross-sectional data from the EUROSTAT, Organization for Economic Cooperation and Development, Statistical Office of the Slovak Republic and the Czech Statistical Office, and the links between determinants were calculated by regression, correlation analysis (F-test). Regression and correlation analyses involve identifying the relationship a dependent variable and independent variable or variables. This paper consists of five sections. Next section discusses the conceptual framework and research related to higher education structure, the role of higher education etc. Section 
three discusses methodology and data, which were used in our paper. The last two sections are dedicated to the results, discussion and conclusions.

\section{Theoretical Background}

Higher education institutions (HEI) have progressively been called upon in last years to prepare the students to work for the global world, and universities are forced to develop graduates' employability globally (Suleman, 2017). On the other hand, the graduate unemployment is following to Hossain, Yagamaran, Afrin, Limon, Nasiruzzaman and Karim (2018) an unwelcome issue that may occur in every country around the world, and as long, the person is involved in the labour market, he or she may one day become unemployed. It is these two economic-social terms that underlie the scientific research of many authors. Over the last years, the number and variety of graduates entering the labour market have raised obviously. This expansion of HE has produced a great number of highly skilled employees, whose employment prospect have become more unpredictable than used to be some years ago (Nunez \& Livanos, 2010). Graduates (HEI) do not represent just a highly skilled workforce, otherwise, they are holders of a high potential to own human capital - so they may increase productivity of firm, may create new jobs, and discover new innovative production processes, as well (Rafaj \& Rehak, 2016).

We have to understand, that also technology has become internationalized (Kordos \& Vojtovic, 2016), so employers need high-skilled workforce, because, as Mura, Haviernikova and Machova (2017), Haviernikova et al. (2018) mention, the changes in economic globalization and development of different countries in recent decades have modified the ways and forms of doing business. Employability is predominantly conceptualized as the skills and personal attributes considered important by industry and needed by graduates in order to secure employment. Generally, it expresses the potential to get a desired job (Rowe \& Zegwaard, 2019). Employability, related to Lisa, Hennelova and Newman (2019) means a set of three skill groups: generic skills, discipline-specific skills and personal attributes. A lot of authors agreed, that main generic skills are teamwork, communication skills, organizing, planning etc., skills in engineering, law, social work are part of discipline-specific skills and personal attributes are represented by self-confidence, resilience, loyalty and integrity (Tupa, 2016). Following to Robinson and Hocenski (2019) research, employers looking for welldeveloped young people with a number of attributes (willingness to learn, enthusiasm, and motivation). Employability - related to Suleman (2017) can be recognized as an ability to get a job, keep it, or find another one. Also Matsouka and Mihail (2016) mention, that employability formed by a set of abilities, experiences, attitudes and personal skills that allow the university graduate to search and get a job. Wilczynska, Batorski, Torrent-Sellens (2014) mention, that basic salary, atmosphere in the workplace, supervisor's approach, employment stability and fringe benefits are the most important motivation factors in Slovakia and the Czech Republic.

On the other hand, Hossain, Yagamaran, Afrin, Limon, Nasiruzzaman and Karim (2018) see the main reason of unemployment of graduates in mismatching of skills between recent graduates and employers demands, as same as in market conditions and foreign workers. Helyer and Lee (2018) look at the root, which affecting unemployment of graduates. The main reason for it is, that we meet a negative phenomenon the educational system is focused on outcomes and placed against the challenges of a global economy that appreciates the imagination and creativity of employees. The major unemployment theories in the West include the involuntary unemployment theory of the Keynesian school, the neoclassical synthesis school, voluntary unemployment theory of the classical school (Wu, 2018).

A knowledge-based economy, related to Paenak, Kovac, Kacer and Skypalova (2018), Volchik et al. (2018) one of the most powerful ways for a country to be stable even in the conditions of sharp competition. The high economic potentiality of the country includes high-quality human resources (HR) which are skilled, professional, effective, flexible, creative, and team-oriented. The mission of universities is to develop harmonious personality, knowledge, wisdom and also creativity to contribute to the development of education and culture for the welfare of the whole society (Ishchenko-Padukova et al., 2017; Vojtovic \& Krajnakova, 2011). The transition of graduates from university to work is simply one of the most important periods in the construction of their adult life, as well. We have to say, that each of three factors have the same importance: institutional settings (means educational opportunities, public youth employment policies and so on), personal decisions, social and cultural frameworks as gender, geographical origin, etc. are (Navaro-Cendejas \& Fachelli, 2018; Draskovic \& Bilan, 2019). The role of the universities is essential in improving employability abilities since their graduates must hold the required qualifications to work professionally in the so-called "learning age" or "learning society" environment (Matsouka \& Mihail, 2016). Challenge to improve graduates' employability skills has raised since the development of higher education and the Bologna Process issues that completely reframed the worldwide educational policies and set the smooth transition from university-work and the employability possibilities of graduates at the front of education policy. A basic assumption in this process is that an increase in level of education in the population, cause of prerequisite for economic growth and job opportunities (Stiwne \& Alves, 2010). The employability of graduates has started to become a new mission of high education at the academic and institutional levels (Suleman, 2017). Zupanec et al., (2018) think, that over the last decade, also the use of ICT (information and communication technologies) has been rapidly spread, but generally, the success of and individual due to transition to labour market is determined above all by his or her skills.

We could defined it as the capacity for carrying out complex, well-organized patterns of behavior smoothly and adaptively so as to achieve some end or goal (Balcar et al., 2018). We also have to say, that higher education is one of the major part of strategy Europe 2020 and target is to achieve at least $40 \%$ of young people aged thirty-thirty four years having completed HE qualification (Mitkova et al., 2018). Blazquez, Herrarte and Llorente-Heras (2018) deal with an idea, that today's societies require high levels of specific skills and abilities that allow individuals to adapt to 
a changing society an perform new tasks. Suleman (2017) mention, that universities should provide valuable abilities and give ready for labour market graduates. This view implies that employability is essentially a matter of individual skills and HE institutions cannot ignore it but should adapt and react to the demand for the requirements of the labour market. Rodriguez-Esteban, A., Vidal, J., Vieira, MJ. (2019) mention, that the successfulness of the institutions of HE may be assessed not only from the point of view of employability of students on the labour market. On the other hand, Aida, Norailis, Rozaini (2015) write about today's graduates as an important part of labour market. They need to understand, that their attitude to work is as important as the work itself. Mainly their willingness and ability to undertake professional development and training throughout their working life will be a pre-requisite for lifelong work.

Regarding to Omar, Manaf, Mohd, Kassim and Aziz (2012), employers at the global and also national economies tend to recruit HEI graduates with high soft skills competencies. Otherwise, related to the incapacitation of graduate soft skills, HEI has come under pressure to equip students with more than academic skills. Singh, G.K.G., \& Singh, S.K.G. (2008) mention, that universities have to make more explicit efforts to develop "core, key, transferable, employable, soft and generic skills", that are needed in many types of employment. Konig, Helyer and Lee (2018) consider the debate around the employability of graduates and adult education level as not a new one (it has been the subject of wide-ranging academic research for the past 25 years). Strategy Europe 2020 target is to achieve at least $40 \%$ of young people aged 30-34 years having completed HE qualification. On the other hand, it's necessary to show also adult education level of Czech and Slovak Republic between 25-64 years. We compare this data with OECD average and as we can see in figure 1, value of adult education level of Slovaks and Czechs is too low.

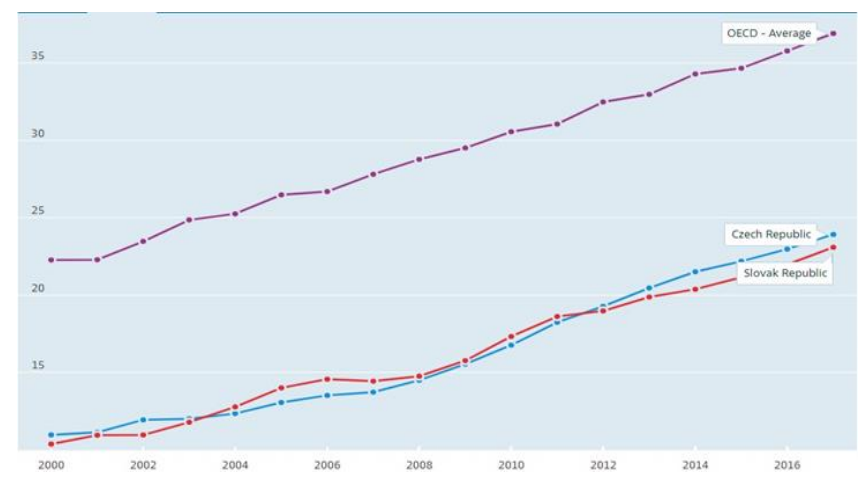

Figure 1. Adult Education Level (25-64 year-olds; 2000-2017) Source: OECD, 2019, Authors' own elaboration

Related to Marsikova, Urbanek (2015) far less attention is paid to job-mismatches referring mainly to the field of obtained education. Sloane (2003) mentions about three reasons of the job-mismatch. The first one is, that schoolleavers have to complete for the available jobs with those who have already gained a position on the labour market. Then, secondly, school-leavers end up in paid-jobs that do not match their educational qualification. The thirdly, there is imbalance of use of gained abilities and qualification.
Finally, Rhoades and Slaughter (2006) challenge empirical research on the mutual relationship between higher education and work. They arguing, that there are some assumptions about employability and work that are never contested - work often equals sector employment (private), work equals employment in very large companies, education for work equals fitting in and assimilating to existing workplaces, preparing for work equals developing new job skills and finally, work equals paid employment.

For the subject of our research, we have to evaluate some of the most important studies from the issue of tertiary graduates employability. Blazquez, Herrarte, LlorenteHeras (2018), using cross-sectional data from the REFLEX Project and investigating the effect of personal competencies among European university graduates. Their research concluded, that non-cognitive skills appear to be much more associated with graduates' occupational status (managerial occupations), than cognitive skills. Noncognitive: ability to negotiate effectively, to perform well under pressure, to coordinate activities, to use time efficiently, to work productively with others, to mobilize the capacities of others, to make clear meaning to others, to assert authority, to present products, ideas to an audience. Cognitive skills: mastery of own field or discipline, knowledge of other fields or disciplines, analytical thinking, ability to rapidly acquire new knowledge, alertness to new opportunities, ability to use computers and the Internet, to come up with new ideas and solutions, willingness to question your own and other's ideas, ability to write reports, memos, or documents, write and speak in a foreign language.

On the other hand, research by Balcar, Simek, Filipova (2018), focusing to evaluation of soft skills of graduates from Czech public universities (direct impact on their employability). They found out, that same soft skills are important for university graduates as for the population as whole (except problem solving). Employers perceive the level of graduates' soft skills as insufficient. The biggest shortcomings of graduates are seen in the case of leadership, problem solving, independence, planning and organizing. Suleman (2017) summarized the employability skills as follows: Graduates (analytical skills, physical attributes, attitudes towards work, personal skills); Employers (attitudes towards work, willingness to learning, foreign language, problem-solving, openness, and personal skills); Engagement (communication skills, team-oriented work, analytical and critical thinking, learning abilities, IT literacy, organizational and planning skills). Matsouka, Mihail (2016), related to quantitative methodology - involving 178 entrants into the labour market of US, as same as 29 human resource managers, found out, that students and graduates require to take the initiative and develop their professional way in the time of studies and to ask available vocational leadership. Organizations are searching for those abilities, i.e learning engagement, team-oriented work, honesty and communication skills. Nunez and Livanos (2010) investigated his effect of an academic degree on unemployment (EU Labour Force survey/ EU-LFS). They found out, that employees with academic degrees have more opportunities of being employed (comparing with those whose holding medium education) than short-term unemployed; Gender influences the opportunities of being employed for the individual. Females have lower chances of employment; the older individuals are having the 
lower chances of being employed rather than unemployed; Social business and law, as a reference category of field of study effects to employability of HEI graduates provides nearly similar employment chances as Health and Welfare, Engineering or Education science.

\section{Methodology and Data}

To clarify the employment and unemployment of HEI graduates (tertiary educated) in conditions of Czech and Slovak Republic we selected from OECD, EUROSTAT, Statistical Office of the Slovak Republic and Czech Statistical Office data, set individuals aged between 25-34 (population with tertiary education) and 25-64 years (adult education level, un/employment rate by tertiary education level), as same as data from foreign and also domestic literature for clarifying the theoretical background. The research paper aimed to identify a causal link between un/employment of tertiary educated persons, both, in Slovak and Czech Republic and a determinants of GDP, FDI and Gross domestic expenditure on research and development by higher education sector (2006-2017). For this purpose, the indicators of gross domestic product, gross domestic expenditure on research and experimental development by sector of higher education and Foreign Direct Investment (FDI) were chosen. By OECD (2019), we can define Gross domestic product (GDP) as the standard measure of the value added created through the production of goods and services in a country during a certain period. It also measures the all income earned from that production - or the total amount spent on final goods and services (less imports). GDP is the most important indicator to capture economic activity. GDP is based on nominal GDP and is available in different measures. For our research, we will measure it in US dollars and US dollars per capita (current PPPs).

Following to EUROSTAT (2019) methodology, the indicator measures gross domestic expenditure on $R \& D$ (GERD) is a percentage of the gross domestic product (GDP). "Research and experimental development (R\&D) comprise creative work undertaken on a systematic basis in order to increase the stock of knowledge, including knowledge of man, culture and society and the use of this stock of knowledge to devise new applications". The relationship between unemployment and employment will be measured for GERD separately for higher education sector. Foreign Direct Investment (FDI) stocks, following to OECD (2019) measure the total level of DI at a given point in time, usually the end of a year. FDI stock is the value of the resident investors' equity in and net loans to enterprises in foreign economies. FDI stocks are measured as a share of GDP and finally, creates stable and long-lasting links between economies. Links between determinants were calculated by regression and correlation analysis. Regression and correlation analysis serves to recognition of statistical dependence between quantitative statistical features. Linear regression: $Y=\beta{ }_{-}+$ $\beta \_1 \mathrm{X}$. Point estimate is: $\mathrm{y}_{-} \mathrm{j}^{\prime}=\mathrm{b}_{-} 0+\mathrm{b}_{-} 1 \mathrm{x} \_\mathrm{j}$ where $\mathrm{b} \_0$ (locating constatnt), b_1 (regression coefficient), $x j$ and $y j$ (values of variable).

\section{Results and Discussion}

Thanks to the study of available OECD, EUROSTAT statistical data, as same as Statistical Office of the Slovak Republic and Czech Statistical Office data, We have analysed in detail unemployment and employment rates of higher education graduates for a longer period of time (1994-2017).



Figure 2. Unemployment Rate by Tertiary Education Level (25-64 year-olds; 1994-2017)

Source: OECD, 2019, Authors' own elaboration

Unemployment of HEI graduates is one of the important statistics that is monitored at national and also international level relatively intensive. In conditions of the Czech Republic has begun with in 1994, in the territory of the Slovak Republic, the first results are known only since 1998. OECD countries, with which we compare measured values started with the records in 1997, when the value of graduate unemployment was at $2,83 \%$. The OECD average values are not consistent, as can be seen in the development framework. The highest unemployment was measured in 2013, when the value of graduate unemployment reached $5,26 \%$. Last measured value in 2017 was 4,07 \%. In 1997, the Slovak Republic reported an unemployment at 2,83\%. The development curve of the measured values takes on an unstable character, especially following the comparison values with the OECD average. Highest value of unemployment was measured in 2013 , namely $6,44 \%$. The current value is set at 3,64\%. The Czech Republic has been listed since the beginning of the monitoring deeply below the OECD average. In the first year (1994) was the value of HEI graduates unemployment at $0,89 \%$. Highest value was measured in 2014, when the unemployment rate was at 2,62 $\%$. However, the situation in the Czech Republic continues to improve, which is also determined by the current measurement (2017), in which the value is set at 1,40\%, which, by the way, is the lowest in the EU27. On the other hand, the higher unemployment rate of HEI graduates was in Greece $(15,7 \%)$ and Spain $(9,3 \%)$.

Employment of higher education graduates since 1995 on average of OECD countries have grown from the original $83,51 \%$ to the current $84,97 \%$. However, there has been a decline in the Czech Republic, from 97,86\% in 1995 to the current $86,04 \%$. On the other side, measured value is higher than average graduate employment of OECD countries (shows figure 3). The Slovak Republic started with measurements in 1997, when $89,76 \%$ of HEI graduates were employed. The fall began after 2008 when the value of employment gradually by 2013 decreased from $85,53 \%$ to $79,46 \%$. 


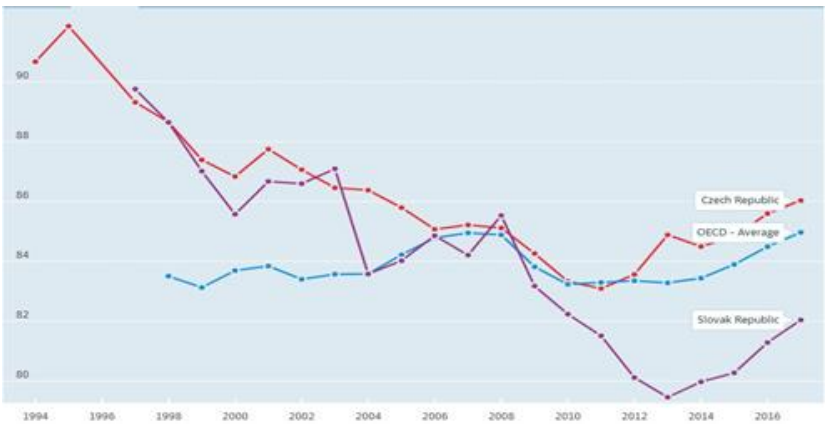

Now, the proportion of employed persons with higher education in Slovakia is significantly below OECD countries, namely, 82,04\%. The biggest employment rate regarding to EU countries. Table 1 shows employment and unemployment rates of HEI graduates by tertiary educational level -both in Slovak and Czech Republic.

Figure 3. Employment Rate by Tertiary Education Level (25-64 Year-Olds; 1994-2017)

Source: OECD, 2019, Authors' own elaboration

Table 1

Unemployment and Employment (Total; \%; Hundreds) in Slovak and the Czech Republic (25-64 Year-Olds) with Tertiary Education (TE, 2006-2017)

\begin{tabular}{|c|c|c|c|c|c|c|c|c|c|c|c|c|}
\hline & 2006 & 2007 & 2008 & 2009 & 2010 & 2011 & 2012 & 2013 & 2014 & 2015 & 2016 & 2017 \\
\hline $\begin{array}{l}\text { Total population } \\
\text { of SR (25-64) } \\
\text { (hundreds) }\end{array}$ & 3040,9 & 3076,4 & 3111,1 & 3140,4 & 3171,8 & 3153,0 & 3165,1 & 3171,1 & 3175,1 & 3174,3 & 3169,9 & 3160,8 \\
\hline $\begin{array}{l}\text { Unemployment SR } \\
(\mathrm{TE}, \%)\end{array}$ & 2,58 & 3,28 & 3,06 & 3,88 & 4,84 & 5,27 & 5,98 & 6,44 & 5,82 & 5,56 & 5,08 & 3,64 \\
\hline $\begin{array}{l}\text { Employment SR } \\
\text { (TE, \%) }\end{array}$ & 84,86 & 84,21 & 85,53 & 83,18 & 82,24 & 81,51 & 80,12 & 79,46 & 79,98 & 80,28 & 81,29 & 82,04 \\
\hline $\begin{array}{l}\text { Unemployed } \\
\text { persons SR } \\
\text { (TE, total) } \\
\end{array}$ & 11454 & 14530 & 14090 & 19252 & 26558 & 30906 & 35962 & 40640 & 37697 & 37240 & 35427 & 26577 \\
\hline $\begin{array}{l}\text { Employed persons } \\
\text { SR } \\
\text { (TE, hundreds) }\end{array}$ & 3768,0 & 3730,0 & 3938,0 & 4127,0 & 4513,0 & 4780,0 & 4818,0 & 5014,0 & 5180,0 & 5377,0 & 5669,0 & 5990,0 \\
\hline $\begin{array}{l}\text { Total population } \\
\text { of CR (25-64) } \\
\text { ( hundreds ) }\end{array}$ & 5979,0 & 6045,2 & 6086,6 & 6096,8 & 6104,1 & 6050,2 & 6017,9 & 5984,5 & 5969,8 & 5949,2 & 5930,2 & 5911,8 \\
\hline $\begin{array}{l}\text { Unemployment } \\
\text { CR } \\
(\mathrm{TE}, \%)\end{array}$ & 2,19 & 1,54 & 1,53 & 2,19 & 2,52 & 2,62 & 2,65 & 2,47 & 2,62 & 2,2 & 1,81 & 1,4 \\
\hline $\begin{array}{l}\text { Employment CR } \\
(\mathrm{TE}, \%)\end{array}$ & 85,07 & 85,22 & 85,12 & 84,26 & 83,33 & 83,09 & 83,56 & 84,89 & 84,5 & 84,83 & 85,6 & 86,04 \\
\hline $\begin{array}{l}\text { Unemployed } \\
\text { persons CR } \\
\text { (TE, total) }\end{array}$ & 17677 & 12754 & 13503 & 20696 & 25842 & 28850 & 30778 & 30303 & 33628 & 29056 & 24688 & 19781 \\
\hline $\begin{array}{l}\text { Employed persons } \\
\text { CR } \\
\text { (TE, hundreds) }\end{array}$ & 6867,0 & 7058,0 & 7512,0 & 7963,0 & 8545,0 & 9149,0 & 9705,0 & $\begin{array}{c}1041 \\
5,0\end{array}$ & $\begin{array}{c}1084 \\
6,0\end{array}$ & $\begin{array}{c}1120 \\
4,0\end{array}$ & $\begin{array}{c}1167 \\
5,0\end{array}$ & $\begin{array}{c}1215 \\
7,0\end{array}$ \\
\hline
\end{tabular}

Source: OECD, SOSR, CSO 2019, Authors' own elabouration and calculation

Table 1 shows the changes in unemployment and employment of tertiary educated in Czech and Slovak Republic. In the conditions of the Slovak Republic, we can observe an increase in the total population in the period under review, based on data from Statistical Office of the Slovak Republic (2019). According to OECD (2019), the unemployment rate of tertiary educated persons in the Slovak Republic increased until 2013 - on the contrary, the values of employment rate of tertiary educated persons reached non-constant values (OECD, 2019). Related to the absence of absolute values of the number of employed and unemployed - tertiary educated persons in the territory of the Slovak and Czech Republic, we calculated these values individually. The population in the Czech Republic increased in the period under review only until 2010, since it has been falling. The values of the total employment and unemployment rate of tertiary educated in the Czech Republic, according to OECD (2019), recorded both, a downward and an upward trend. In connection with the above mentioned facts, we have defined three basic indicators, by means of which we will verify the relationship between employment and unemployment of tertiary educated in the Slovak and Czech Republic. In the individual measurements, we will examine the regression relationship between employment/unemployment and development of GDP (US dollar per capita); Gross domestic expenditure on R\&D by Higher education sector; Foreign Direct Investment (FDI). In the first case, we used the regression analysis to find out the mutual regression relationship between employment and unemployment of tertiary education graduates separately for the Czech and Slovak Republic and the development of GDP. Based on measurement, we found the following: 
Regression of Unemployed with Tertiary Education and GDP (SR/CR)

\begin{tabular}{|c|c|c|c|}
\hline \multicolumn{2}{|c|}{ Regression (GDP/SR/Unemployment) } & \multicolumn{2}{|c|}{ Regression (GDP/CR/Unemployment) } \\
\hline Regression Statistics & & Regression Statistics & \\
\hline Multiple R & 0,784342 & Multiple R & 0,357107 \\
\hline R Square & 0,615192 & R Square & 0,127526 \\
\hline Adjusted R Square & 0,576711 & Adjusted R Square & 0,040278 \\
\hline Standard Error & 6775,036 & Standard Error & 6842,67 \\
\hline Observations & 12 & Observations & 12 \\
\hline \multicolumn{2}{|c|}{ Regression (GDP/SR/Employment) } & \multicolumn{2}{|c|}{ Regression (GDP/CR/Employment) } \\
\hline Regression Statistics & & Regression Statistics & \\
\hline Multiple R & 0,976621 & Multiple R & 0,953484 \\
\hline R Square & 0,953789 & R Square & 0,909132 \\
\hline Adjusted R Square & 0,949167 & Adjusted R Square & 0,900045 \\
\hline Standard Error & 16849,37 & Standard Error & 58422,09 \\
\hline Observations & 12 & Observations & 12 \\
\hline
\end{tabular}

Source: Authors' own elaboration

- The regression relationship between unemployment of tertiary educated and the level of GDP in the Slovak Republic is characterized by a moderately strong

correlation (correlation coefficient $=0,784$ ); Significance $\mathrm{F}(\mathrm{xy})<0,05$;

- The regression relationship between unemployment of tertiary educated and the level of GDP in the Czech Republic is characterized by a weak correlation (correlation coefficient $=0,357$;
- The regression relationship between employment of tertiary educated and the level of GDP in the Slovak Republic is characterized by a strong correlation (correlation coefficient $=0,977$ ); Significance $F(x y)<0,05$;

- The regression relationship between employment of tertiary educated and the level of GDP in the Czech Republic is also characterized by a strong correlation (correlation coefficient $=0,953)$; Significance $F(x y)<0,0$.



Figure 4. Regression of Unemployed with Tertiary Education and GDP (SR/CR) Source: Authors' own elabouration

The regression function of the relationship between unemployed graduates of tertiary education and the value of GDP in the Slovak Republic has the form $y=1,9992 x-$ 24693 , where $61,52 \%$ of the variability is explained by the linear regression model (in the case of polynomial up to $74,48 \%$ ). In the case of the Czech Republic, the form $\mathrm{y}=$ $0,6066 x+5758,6$, where only $12,75 \%$ of the variability is explained by the model of the linear regression (in the case of polynomial $=49,75 \%$ ). In the second case, we investigated via regression analysis the regression relationship between employment and unemployment of tertiary education graduates separately for the Czech and Slovak Republic and the GERD (HE sector). Based on the measurement we found the following:

Table 3

Regression of un/Employed with Tertiary Education and GERD - HE Sector (SR/CR)

\begin{tabular}{|c|c|c|c|}
\hline \multicolumn{2}{|c|}{ Regression (GERD of HE sectors/SR/Unemployment) } & \multicolumn{2}{|c|}{ Regression (GERD of HE sectors/CR/Unemployment) } \\
\hline Regression Statistics & & Regression Statistics & \\
\hline Multiple R & 0,793792 & Multiple R & 0,808167 \\
\hline R Square & 0,630105 & R Square & 0,653134 \\
\hline Adjusted R Square & 0,593116 & Adjusted R Square & 0,618448 \\
\hline Standard Error & 6642,456 & Standard Error & 4314,495 \\
\hline Observations & 12 & Observations & 12 \\
\hline \multicolumn{2}{|c|}{ Regression (GERD of HE sectors/SR/Employment) } & \multicolumn{2}{|c|}{ Regression (GERD of HE sectors/CR/Employment) } \\
\hline Regression Statistics & & Regression Statistics & \\
\hline Multiple R & 0,733452 & Multiple R & 0,860655 \\
\hline R Square & 0,537951 & R Square & 0,740727 \\
\hline Adjusted R Square & 0,491746 & Adjusted R Square & 0,7148 \\
\hline Standard Error & 53278,61 & Standard Error & 98684,5 \\
\hline Observations & 12 & Observations & 12 \\
\hline
\end{tabular}

Source: Authors' own elaboration 
- The regression relationship between unemployment of tertiary educated graduates and indicator GERD only for HE sector in the Slovak Republic is characterized by a moderately strong correlation (correlation coefficient $=$ 0,794); Significance $F(x y)<0,05$;

- The regression relationship between unemployment of tertiary educated graduates and indicator GERD only for HE sector in the Czech Republic is characterized by a strong correlation (correlation coefficient $=0,808$ ); Significance $\mathrm{F}(\mathrm{xy})<0,05$;
- The regression relationship between employment of tertiary educated graduates and indicator GERD only for HE sector in the Slovak Republic is characterized by a moderately strong correlation (correlation coefficient $=$ 0,733); Significance $F(x y)<0,05$;

- The regression relationship between employment of tertiary educated graduates and indicator GERD only for HE sector in the Czech Republic is characterized by a strong correlation (correlation coefficient $=0,861$ ); Significance $\mathrm{F}(\mathrm{xy})<0,05$.

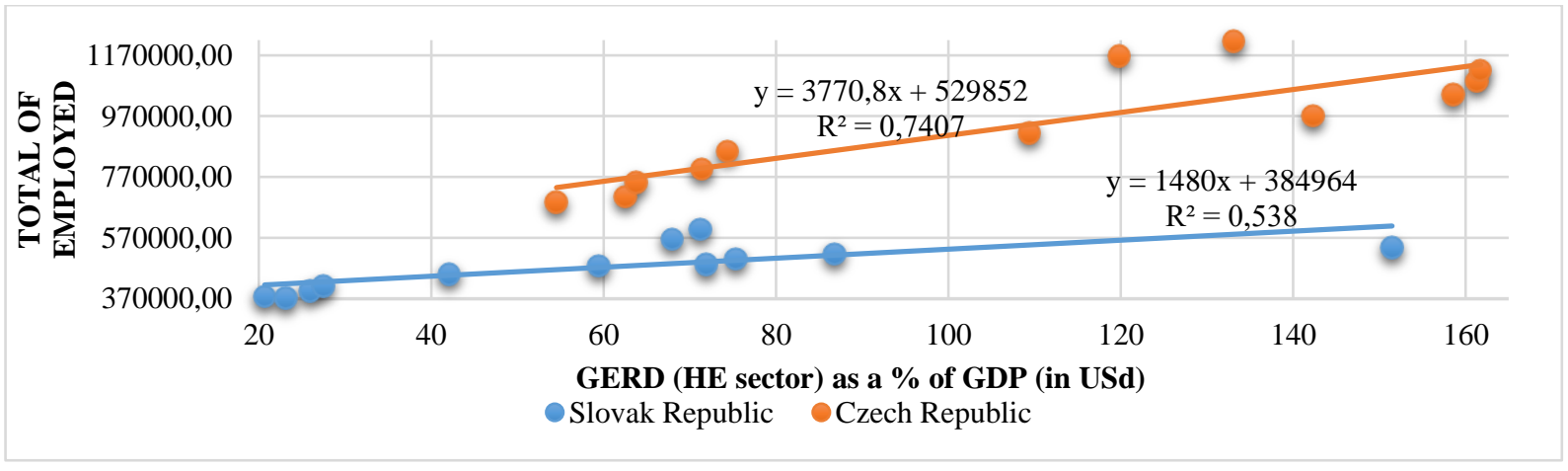

Figure 5. Regression of Employed with Tertiary Education and GERD - HE Sector (SR/CR)

\section{Source: Authors' own elaboration}

The regression function of the relationship of employed tertiary graduates and the value of indicator GERD for the HE in the Slovak Republic has the form $\mathrm{y}=$ $1480 x+384964$, where only $53,80 \%$ of variability is explained by the linear regression model. In the case of Czech Republic, the form is $y=3770,8 x+529852$, where $74,07 \%$ of the variability is explained by the model of the linear regression (in the case of polynomial regression this percentage is at the level of $83,60 \%$ ). In the case of the last measurement, we used the regression analysis to determine the mutual regression relationship between employment and unemployment of tertiary education graduates for both, the Czech and Slovak Republic and the indicator FDI stocks. Based on the measurement we found the following:

Table 4

Regression of un/Employed with Tertiary Education and FDI Stocks (SR/CR)

\begin{tabular}{|l|c|l|l|}
\hline \multicolumn{2}{|c|}{ Regression (FDI/SR/Unemployment) } & \multicolumn{2}{|l|}{ Regression (FDI/CR/Unemployment) } \\
\hline Regression Statistics & & Regression Statistics \\
\hline Multiple R & 0,714335 & Multiple R & 0,301173 \\
\hline R Square & 0,510275 & R Square & 0,090705 \\
\hline Adjusted R Square & 0,461303 & Adjusted R Square & $-0,00022$ \\
\hline Standard Error & 7643,034 & Standard Error & \multicolumn{1}{|c|}{ Regression (FDI/CR/Employment) } \\
\hline Observations Regression (FDI/SR/Employment) & 12 & Observations & \\
\hline \multicolumn{2}{|c|}{} & & Regression Statistics \\
\hline Regression Statistics & 0,580091 & Multiple R & 0,906209 \\
\hline Multiple R & 0,336505 & R Square & 0,821215 \\
\hline R Square & 0,270156 & Adjusted R Square & 0,803336 \\
\hline Adjusted R Square & 63845,11 & Standard Error & 81947,62 \\
\hline Standard Error & 12 & Observations & \\
\hline Observations & & & 12 \\
\hline
\end{tabular}

Source: Authors' own elaboration

- The regression relationship between unemployment of tertiary educated graduates and indicator FDI Stocks in the Slovak Republic is characterized by a moderately strong correlation (correlation coefficient $=0,714$ ); Significance $\mathrm{F}(\mathrm{xy})<0,05$;

- The regression relationship between unemployment of tertiary educated graduates and indicator FDI Stocks in the Czech Republic is characterized by a weak correlation (correlation coefficient $=0,301)$;
- The regression relationship between employment of tertiary educated graduates and indicator FDI Stocks in the Slovak Republic is characterized by a moderately strong correlation (correlation coefficient $=0,580$ ); Significance $\mathrm{F}(\mathrm{xy})<0,05$;

- The regression relationship between employment of tertiary educated graduates and indicator FDI Stocks in the Czech Republic is characterized by a strong correlation (correlation coefficient $=0,906)$; Significance $F(x y)<0,05$. 


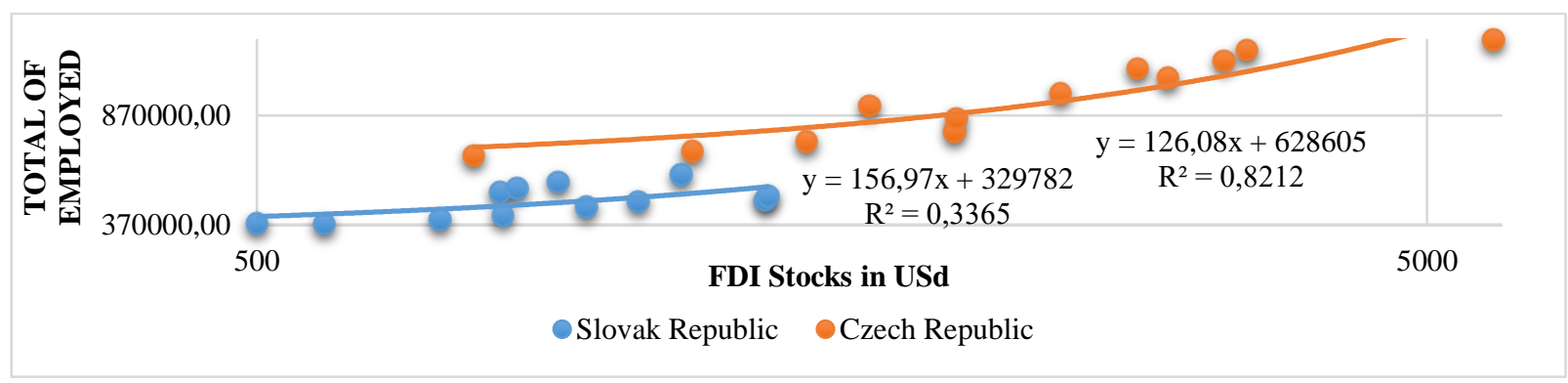

Figure 6. Regression of Employed with Tertiary Education and FDI Stocks (SR/CR) Source: Authors' own elaboration

The regression function of the relationship between employed tertiary graduates and the value of FDI stocks in the Slovak Republic has the form $y=156,97 x+329782$, where only $33,65 \%$ of variability is explained by the linear regression model. In the case of Czech Republic, the form is $y=126,08 x+628605$, where $82,12 \%$ of the variability is explained by the model of the linear regression (in the case of polynomial regression this percentage is at the level of $92,36 \%)$.

\section{Conclusions}

Rehak et al. (2015) discuss a massive increase in higher education in Slovakia, where the total number of university students in 2008 was 3-times bigger than in 1990. Also, according to Centre of Scientific and Technical Information of Slovak Republic, in 1997, only 11 cities were provided master level studies, while in 2015 this type of study was provided in 18 cities. The situation regarding the increasing number of Higher Education Institutions in conditions of Slovak and Czech Republic is quite same, but some differences are visible. Related to Soukalova and Gottlichova (2015), expansion and diversification of higher education, mainly in Czech Republic is alarming. In 2000, there were only 24 public and 8 private universities, while in 2012 there were 44 private universities (26 public). In conditions of Slovakia 35 universities (12 of them private) provide services. As stated by Rafaj and Rehak (2016), to achieve balanced development in regions of Slovakia, we have to continue in the diversification of production of university and college graduates, as well as focus on the factor of human capital. It is very important to look at every region independently because of differentiation among structure of graduates. It is necessary to have the constructive cooperation and above-average communication of HEI with economic sector. In many cases, high-educated possess more knowledge than required, but they are missing important skills and competences, that the job market demands, what can, ultimately, lead to migration, because there have never been such favorable conditions for migration of young's as in today's era of globalization (Streimikiene et al., 2016).

The causality relationships between mobility factors such as emigration, foreign direct investment, GDP etc. examine Tupa, Vojtovic (2018), Danaj et al. (2018) and others. In the last monitored period (2017), the population with tertiary education in the territory of the Slovak and the Czech Republic was far below the OECD average. In the case of the Czech Republic, the education level was about
$33,8 \%$, in the case of the Slovak Republic $35,1 \%$. In the light of the above, we have to say, that the objective of the Europe 2020 strategy is far from being achieved in case of Czech Republic and Slovakia. Although in connection with the education of 25-64 years old, both countries have a slightly increasing trend, but there are still far below the OECD average. In our paper, we have clearly demonstrated not only the position of the Czech and the Slovak Republic in the OECD or EU, but also the position of countries in their mutual confrontation with regard to employment, unemployment and the education level of the population.

To assess the reasons for the relatively large disparities, we used one of the most frequently reported statistical methods - representing by the degree of linear association between two variables. Following the measurements, we found that the disproportion between employment and unemployment among higher educated in the countries under review occurred mainly when examining the regression relationship and the subsequent comparison between each indicator. The correlation between unemployment of higher educated Slovaks and GDP values was significantly stronger in comparison with the same correlation in Czechia $(0,784>0,357)$. Based on this finding, we can say, that increasing or decreasing of GDP per capita significantly affects unemployment of higher educated in the Slovak Republic. On the other hand, measurements related to correlation between employment of higher educated and GERD (but only for expenditures by higher education sector) show, as same as the FDI, that there is significantly stronger correlation between employment of higher educated Czechs than Slovaks $(0,861>0,733)$ regarding to expenditures by higher education sector and FDI $(0,906>0,580)$. The last-mentioned FDI value show almost perfect linear dependence (up to 0,90). We made sure wellnigh in all significant measurements (calculating F-test), that the models were chosen correctly, because of Significance $\mathrm{F}(\mathrm{xy})<0,05$ (probability $=95 \%$ ). It is important to point out the need to continue with research into the un/employability of HEI graduates in the labour market - however, not only in relation to competency models. Future research offers opportunities to explore the relationship between other macro and micro economic determinants (as same as the determinants of economic development) and the un/employment rates of tertiary educated graduates at different timescales. The benefit of this study is mainly in the theoretical level, which can be used in the designing of Reform of Education system in specific fields of study and study programs, which is a current issue. 


\section{References}

Aida, B., Norailis, A.W., \& Rozaini, R. (2015). Critical Success Factor of Graduate Employability Programs. Journal of Economics, Business and Management, 3(8), 767-771. https://doi.org/10.7763/JOEBM.2015.V3.283

Aman, M., \& Sitotaw, M. (2014). Perception of Summer Cooperative Graduates on Employers Generic Skills Preference, Haramaya University, Ethiopia. International Journal of Instruction, 7 (2), 181-190. e-ISSN: 1308-1470.

Balcar, J., Simek, M., \& Filipova, L. (2018). Soft Skills of Czech Graduates. Review of Economic Perspectives Narodoospodarsky Obzor, 18 (1), 45-60. https://doi.org/10.2478/revecp-2018-0003

Blazquez, M., Herrarte, A., \& Llorente-Heras, R. (2018). Competencies, occupational status, and earnings among European university graduates. Economics of Education Review, 62, 16-34. https://doi.org/10.1016/j.econedurev.2017.10.006

Cao Bao, T. (2018). University Graduates and Employment: the Gap between Employer Expectations and Graduate Performance. Journal of Science, 15 (5b), 128-138.

Czech Statistical Office. (2019). Age Distribution of the Population (2006-2017). (accessed 20 May 2019) Available online: https://www.czso.cz/csu/czso/age-distribution-of-the-population-2017

Danaj, A., Lazanyi, K., \& Bilan, Y. (2018). Perceptions and implications of immigration in france - economic, social, political and cultural perspectives. Economics and Sociology, 11(3), 226-247. https://doi.org/10.14254/2071789X.2018/11-3/14

Draskovic, V., \& Bilan, S. (2019). Perception of the social status of intelligence in selected countries of the former yugoslavia. Economics and Sociology, 12(2), 319-327. https://doi.org/10.14254/2071-789X.2019/12-2/19

Eurostat (2019). Gross domestic expenditure on R\&D by sector. (accessed 25 Jun 2019) Available online: https://ec.europa.eu/eurostat/databrowser/view/sdg_09_10/default/table?lang=en

Haviernikova, K., Kordos, M., \& Navickas, V. (2018). The motivation of slovak small and medium entrepreneurs towards cluster cooperation. Transformations in Business and Economics, 17(3), 91-101.

Helyer, R., \& Lee, D. (2014). The Role of Work Experience in the Future Employability of Higher Education Graduates. In: Higher Education Quarterly, 68 (3), 348-372. https://doi.org/10.1111/hequ.12055

Hossain, M. I., Yagamaran, K. S. A., Afrin, T., Limon, N., Nasiruzzaman, M., \& Karim, A. M. (2018). FactorsInfluencing Unemployment among Fresh Graduates: A Case Study in Klang Valley, Malaysia. International Journal of Academic Research in Business and Social Sciences, 8 (9), 1494-1507. https://doi.org/10.6007/IJARBSS/v8-i9/4859

Ishchenko-Padukova, O., Kazachanskaya, E., Movchan, I., \& Nawrot, L. (2017). Economy of education: National and global aspects. Journal of International Studies, 10(4), 246-258. https://doi.org/10.14254/2071-8330.2017/10-4/19

Konig, LS., Robinson, R., \& Hocenski, M. (2019). What Do Employers in Croatia and Ireland Want? 8th International Scientific Symposium Economy of Eastern Croatia - Vision and Growth, 959-977. ISSN: 1848-9559

Kordos, M., \& Vojtovic, S. (2016). Transnational Corporations in the Global World Economic Environment. International Conference on New Challenges in Management and Business: Organization and Leadership. Dubai: Book Series: Procedia Social and Behavioral Sciences. 230, 150-158. https://doi.org/10.1016/j.sbspro.2016.09.019

Krajnakova, E., \& Vojtovic, S. (2011). Development of Science and Education among the Priorities of State. In: 8th International Conference on Efficiency and Responsibility in Education. Prague: CZU 147-156.

Krajnakova, E., \& Vojtovic, S. (2017). Struggles of Older Workers at the Labour Market. Economics \& Sociology, 10 (1), 319-333. https://doi.org/10.14254/2071-789X.2017/10-1/23

Lisa, E., Hennelova, K., \& Newman, D. (2019). Comparison between employers' and students' expectations in respect of employability skills of university graduates. International Journal of Work-Integrated Learning, 20 (1). 71-82.

Matsouka, K., \& Mihail, M.D. (2016). Graduates'employability: What do graduates and employers think? Industry and Higher Education, 30 (5). 321-326. https://doi.org/10.1177/0950422216663719

Mura, L., Haviernikova, K., \& Machova, R. (2017). Empirical Results of Entrepreneurs' network: Case Study of Slovakia. Serbian Journal of Management, 12 (1), 121-131. https://doi.org/10.5937/sjm12-10418

Nunez, I., \& Livanos, I. (2010). Higher education and unemployment in Europe: An analysis of the academic subject and national effects. https://doi.org/10.1007/s10734-009-9260-7

Omar, H. N., Manaf, A. A., Mohd, H. R., Kassim, CH. A., \& Aziz, A. K. (2012). Graduates' Employability Skills Based on Current Job Demand through Electronic Advertisement. Asian Social Science, 8 (9), 103-110. https://doi.org/10. 5539/ass.v8n9p103

Paenak, P., Kovac, U., Kacer, J., \& Skypalova, M. (2018). Impact of University Degree on the Labour Market in Slovakia. 36th International Scientific Conference on Economic and Social Development - "Building Resilient Society", Zagreb, 14-15 December 2018, pp. 644-652. 
Emilia Krajnakova, Vaida Pilinkiene, Patrik Bulko. Determinants of Economic Development and Employability of Higher...

Rafaj, O., \& Rehak, S. (2016). Spatial Aspects of University Graduates in Slovakia. GeoScape, 10 (2), $26-34$. https://doi.org/10.1515/geosc-2016-0003

Rehak, S., Dzupka, P., Sebova, M., \& Sekelsky, L. (2015). Lokalne ekonomicke vplyvy univerzit. Bratislava: Ekonom,

Rodriguez-Esteban, A., Vidal., J., \& Vieira, MJ. (2019). An analysis of employability of Spanish graduates through the Horizontal Match. Revista de Educacion, 384, 221-245.

Rowe, A.D., \& Zegwaard, K. E. (2019) Developing gradate employability skills and attributes: Curriculum enhancement through work-integrated learning. Asia-Pacific Journal of Cooperative Education, Special Issue, 18 (2), 87-99.

Singh, G. K. G., \& Singh, S. K. G. (2008). Malaysian graduates' employability skills. UniTAR e-Journal, 4 (1), $15-45$.

Statistical Office of the Slovak Republic (2019). DATACube. (accessed 20 May 2019) Available at: http://datacube. statistics.sk/

Stiwne, E. E., \& Alves, M. G. (2010). Higher Education and Employability of Graduates: will Bologna make a difference? European Educational Research Journal, 9(1), 32-44. https://doi.org/10.2304/eerj.2010.9.1.32

Streimikiene, D., Bilan, Y., Jasinskas, E., \& Griksaite, R. (2016). Migration trends in Lithuania and other new EU member states. Transformations in Business and Economics, 15(1), 21-33.

Su, W., \& Zhang, M. (2015). An integrative model for measuring graduates' employability skills - A study in China. Cogent Business \& Management. https://doi.org/10.1080/23311975.2015.1060729

Suleman, F. (2017). The employability skills of higher education graduates: insights into conceptual frameworks and methodological options. High Education, 76, 263-278. https://doi.org/10.1007/s10734-017-0207-0

Tupa, M. (2016). Impacts of Labour Migration on Development and Amount of Salary. Bulgaria. SGEM, 2016: Political Sciences, Law, Finance, Economics and Tourism, Conference Proceedings, Vol. V., Pages: 321-328.

Tupa, M., \& Vojtovic, S. (2018). Impact of Brexit on The Migration in The UK. AD ALTA - Journal of Interdisciplinary Research, 8 (2), 306-309.

Urbanek, V., \& Marsikova, K. (2015). Risk of Investment to Higher Education. Proceedings of the 21th International Conference, Theoretical and Practical Aspects of Public Finance 2016. Vysoka skola ekonomicka v Praze: Oeconomica, pp. 319-325.

Volchik, V., Oganesyan, A., \& Olejarz, T. (2018). Higher education as a factor of socio-economic performance and development. Journal of International Studies, 11(4), 326-340. https://doi.org/10.14254/2071-8330.2018/11-4/23

Wilczynska, A., Batorski, D., \& Torrent-Sellens, J. (2014). Employment Flexibility and Job Security as Determinants of Job Satisfaction. Social Indicators Research, 162(2), 633-656. https://doi.org/10.1007/s11205-015-0909-6

Wu, XG. (2018). The Enlightenment of Western Unemployment Theory on the Hard Employment of College Graduates. 2nd International Conference on Education, Economics and Management Research (ICEEMR), 182, 284-286. ISBN: 978-94-6252-521-4. https://doi.org/10.2991/iceemr-18.2018.64

Zupanec,V. S., Radulovic, B. N., Priblicevic, T. Z., Miljanovic, T. G., \& Zdravkovic, V. G. (2018). Determination of educational efficiency and students' involment in the flipped biology classroom in primary school. Journal of Baltic Science Education, 17 (1), 162-176. http://oaji.net/articles/2017/987-1519060434.pdf

The article has been reviewed.

Received in November 2019; accepted in April 2020. 